\title{
Influence of Principals' Involvement of Students in Decision Making on Discipline in Secondary Schools, Kenya
}

\author{
Patrick Wambua \\ Doctor of Education Student, University of Nairobi, Kenya \\ Ursula A. okoth \\ Jeremiah M. Kalai \\ Lecturer, School of Education, University of Nairobi, Kenya
}

doi: 10.19044/esj.2017.v13n22p227 URL:http://dx.doi.org/10.19044/esj.2017.v13n22p227

\begin{abstract}
Stakeholder involvement is critical in that it can enhance levels of ownership of the decisions made as well building trust between the governors and the governed. The purpose of the study was to investigate the influence principals' involvement of students in decision making on student discipline in secondary schools, Kenya. The study sought to establish the areas of student involvement in decision making by secondary school principals and determine whether significant differences exist between reported incidences of student indiscipline based on the levels of student involvement in decision making in secondary schools. The study employed systems theory by Ludwig Bertalanffy which looks at organisations as systems. Schools are viewed as parts joined together by web of relationships both within and outside the school. Using a descriptive survey design with a target population of 354 secondary school principals, 300 teachers and 4602 student leaders, a sample of 118 principals and 1534 student leaders were sampled through stratified proportionate sampling. Questionnaires for principals and student leaders were used for the study. The return rate was 101 principals (85.6\%) and 1433(93.4\%) student leaders. Cross-tabulations were done to determine whether the mean occurrences of student indiscipline were different based on levels of principals' involvement of students in decision making. The findings indicated that 94.1 per cent of principals involved students in decision making with varying degrees of involvement for student welfare. Analysis of Variance (ANOVA) did not indicate significant differences between involvement in decision making and lowering of cases of drug and substance abuse, cases of arson and student suspension. The incidences of student indiscipline in those schools were low, as evidenced by lowered cases of arson factor that could be attributed to
\end{abstract}


students sense of ownership and feeling respected and recognised. The study concluded that involvement in decision making is a key driver to student's discipline. The study could be replicated in a number of counties involving teachers and Board members as respondents. In addition, the study could be replicated using mixed methods with more inclination to the qualitative research.

Keywords: Democratic governance, Student discipline, participatory decision making

\section{Introduction}

Interest in participatory governance in established institutions is increasing and new forms of governance are emerging with the reality compelling new ways of thinking about collective decision making (Vasurdha, 2008). Adesoji and Adetoro (2015) conducted a study in 12 universities in southern Nigeria and the respondents (Lecturers and students) were in concurrence that that student involvement in decision making was a key predictor of leadership effectiveness and ownership of the decisions arrived at through consensus. Participatory governance involves sensitization towards democratization while decentralization of school administration is the diffusion of the decision making process to include all the members of the school (Njogu, 2004). American schools just like English ones seek to maintain social order, teaching their students on leadership, authority and responsibility. Koli (2005) observes that some students in America high schools enjoy a more influential role in school authority as student councils. They are official agency making decisions and ensuring that they are carried out.

Involvement in decision making is recommended because participants are usually more satisfied with the decisions they have collectively made and enthusiastically supported. Baraza (2007) avers that student involvement in decision making is a concept that values all components for acceptance and compliance. The student-teacher relationship is improved to the extent that they discuss freely matters affecting the school. Lifton (1990) advocated for involvement of students in decision making in the school governance by arguing that as future leaders, students need to be prepared for making sound decisions. Musyoka (2011) cites Katz and Kahn (1966) who aver that democratization is the extent to which all members share accountability and administrative processes. Mule, Kalai and Mulwa (2017) in a study on principals' characteristics that could influence their involvement of students in decision making observed that different forms of involvement in governance could be employed. These include student councils, peer supporters, peer mentors, school clubs and societies. 
Studies are in agreement regarding the need to involve students at various levels in governance of educational institutions (Adesoji, \& Adetero, 2015, Kigotho, 2009, Kibet, Kindiki, \& Sang, 2012, Kimotho, 2012 \& Musyoka, 2011). What is debatable however is the areas of involvement and the degree to which students at various levels of education can be involved in decision making on issues that affect them. Tikoko and Kiprop (2011) observed the levels of student involvement in decision making are debatable. They cited Sithole (1988) who postulates that there are three viewpoints that prescribe the extent of student involvement in decision making. The first is that students must remain passive and receive instructions from parents and teachers. This view will mean that policies must be designed by adults and students are to follow them to the letter. This form of engagement is considered by theorists of participatory management as the main source of student discontent since they are treated as recipients of information with minimal if any input. Sithole (1988) further explored the second view that suggests that students can participate but only to a certain degree. Some scholars observe tendencies among some teachers and school leaders to define the issues which affect students quite narrowly.

Tikoko and Kiprop (2011) noted that student consultation and decision-making is often limited to aspects of school life that affect students only and which have no immediate relevance to other stakeholders. Students may be excluded from examinations, evaluation of student performance, appointment of teachers and other secret matters, among others. Though this view appears to support student participation in decision making, it however confines student involvement in decision making to specific areas of school life. This approach is regarded by others as tokenistic and therefore not to be taken seriously, but it also severely limits the possibilities for experiential learning (about the nature of schooling and the education system as well as in different forms of public decision-making.

Most unrests in schools result from poor relations between school management and teachers on one hand and students on the other. In some instances, students feel excluded from matters that directly affect them and that they would have a say for their enhanced welfare (Hanson, 1991, Daft\& Marcic, 2006). The Report of the task force on student discipline and unrest in secondary schools (Republic of Kenya 2001) noted that academic pressure particularly during the second term is one of the triggers of student unrests. The desire for improved mean grades in national examinations made and still continues to make teachers and educational managers to exert pressure on students to perform better. The student drilling process and lack of holidays because of holiday tuition sessions was cited as a source of stress, which could culminate in ventilation of such stress through riots. Indiscipline cases crop up when student leaders have the perception that the principal treats 
them like young children as opposed to where they need to be regarded as young adults. The frustration is captured by feeling that "teachers treat us as children and they imagine we cannot think for ourselves".

Kabaka (2005) postulates that administrators should take into consideration age, interest, ambitions and allow nature or individual differences of students to manifest itself and make the student be the best that they can be. The gifted seek peer acceptance by masking talents, conforming to peer behaviour patterns and purposes. This enhances competition and indiscipline. Involvement of peer counsellors in discipline management is crucial as it can nurture students' ability; motivation and creativity; which can enable the school achieve its objectives (Mule, Kalai\& Mulwa, 2017). Involvement of peers is important in that it includes monitoring other student's class attendance, punctuality and overall discipline. Student leaders are in touch with students than any other person and there is need for them to organize the students. The administration need to seek evidence of student leaders' participation in matters of discipline, organization and control of extracurricular activities to have a take on decision. Kato (2007) postulates that student leaders need to be trained on record keeping as is a sign of proper organization. Their records should be up to date to indicate daily attendance for teachers, students, enrolment in class and punctuality. Participatory decision making gives student leaders authority and power to make pertinent decisions over student behaviour matters. Musyoka (2011) has pointed that one of the significant correlates of students behaviour is the extent to which students' involvement in decision making process within the school. The principal plays a critical role in determining how the school community relates. If school policies are favourable in terms of giving members of the school community an opportunity to participate in their formulation, there is likelihood that stakeholders will identify more closely with the laid-down policies. The student will develop positive attitudes towards the school and support it to attain its mission statements of quality grades and disciplined students.

Students learn to make decisions by being members of their school board at early stage with the understanding to breed good future leaders who will be better citizens with decision making capacity (Middle town public schools, 2001). If students are in decision making, they are likely to acquire and respect democratic ideals, which are imperative not only at school level but also in the wider society where they have civic responsibilities and obligations. Participation in decision making is critical for students because:

i) It is their right and they are affected by the decisions made by their seniors.

ii) They learn procedures, responsibility and accountability in decision making and implementation. 
iii) Boards get to know first-hand the students' needs and therefore act accordingly.

iv) They develop positive attitudes towards their school and regard themselves as valued members of the school

v) Students have a better understanding of matters related to their school particularly its administration and as such they tone down their resistance.

vi) Opportunity to know and be part of decisions especially budgets as it's a major cause of unrest and strikes.

vii) The understanding promotes good teacher student relationship and enhances good academic and governance results (Middle town public schools, 2001, Wambua, 2017)

Failure to expose student leaders into decision making in early years encourages docility, stereotyping and blind acquiescence to authority. While this might appear good to educators who may not want to be actively engaged with students' concerns, it has far reaching negative implications. Students in decision making establish protection and smooth implementation of such polices with less fear of the violation and undermining by the same. There is a general assumption the earlier student practice making decisions in high schools the better leaders they will become the school that inculcates the practice is in essence cultivating responsible leadership for future. There are rules, norms and sanctions to control student behaviour or discipline. Small (1999) emphasises the notion that learners involvement in decision making on issues that concern them by indicating that values cannot be asserted, they be put on table, be debated, negotiated, synthesised, modified in order they truly and meaningfully constitute code of conduct that controls students .The first national secondary school student conference bringing together representatives from across the country's secondary schools was held in May 2008.

According to Kenya Secondary Schools Head Association (KSSHA), the 2008 conference took off with a lot of momentum to establish student governments at the classroom and school level in secondary schools across the country. The governments were hoped would create an interactive forum between the students and school administrators where issues affecting them would be discussed before they degenerated into full-blown school riots. The need to set up student governments at school level did not pick up as fast as expected in regions across the country, (KSSSC, 2014). The student councils put the power to demand better learning and teaching services Kindiki (2009), Sang and Kitilit (2012) found that principals of secondary schools communicate and involve students in the management of schools.

Republic of Kenya (2001) stipulates that schools should plan and involve students in planning, implementation and evaluation of appropriate 
governance activities in schools. This is in consistent with the Basic Education Act (2013) which stated that BOM could encourage a culture of dialogue and participatory governance at learning institutions (Republic of Kenya, 2013). This is inconsistent with the study by Muchelle (1996) which sought to investigate attitudes of secondary school principals towards the involvement of students in school administration found that the amount of participation in school administration allowed in the school was not sufficient to give students a chance to practice democratic skills. This was borne out of the understanding that many studies have explored factors that influence managers' involvement of students in governance without identifying the specific areas of interest to the students. Owing to the rampant cases of unrest in Machakos County between 2013 and 2015, Machakos County provided a suitable study location. In addition, the County has had historic tragic student arson cases where lives were lost.

\section{Statement of the problem}

In 2013, two boys' schools and three mixed boarding schools in Matungulu Sub-County went on rampage; gutting down buildings which led to loss of property worth millions of shillings and loss of lives for two boys. Seven secondary schools in Kangundo District went on rampage. In Machakos Sub-County, 15 secondary went on rampage (Machakos County Education Office, 2013). In all of these unrests; there were complaints touching on lack of inclusivity. In 2014, the same trend followed where in a boys' boarding school in Matungulu Sub-County, where the students' unrest was hinged on the same. School property was burnt and two students lost their lives and many left with scars and trauma. In Term two 2015 a record 31 schools in Machakos County had gone on strike in a span of a month (Machakos County Education Office, 2015). The study found out the scope and the areas of students' involvement as a practice since it varies where the schools have students electing their leaders. In Machakos County, there have been cases of violent strikes to the extent of students losing their lives and in earlier years Kyanguli secondary led with a record of 69 deaths, Kinyui boys 2 boys died in 2013 while recently in second term of 2015, 31 schools reported arson and strikes leaving many students critically injured. Studies by Muchelle (1996), Musyoka (2011), indicate that involvement of students in management of secondary schools draws a lot of public acclaim but it is given lukewarm support by principals who are central drivers to its implementation. This is despite of the suggestive evidence that involvement in decision making has the capacity to stem the tide of students' indiscipline. This study therefore sought to investigate the underlying question of whether use of participatory management has influence on students' discipline. 


\section{Purpose of the study}

This study sought to investigate the influence of principals' involvement of students in decision making on discipline of students in secondary schools in Machakos County, Kenya.

\section{Research objectives}

They determine the study approach based on the key areas of concern and guides the researcher on the appropriate basis to undertake the study

i) To establish the levels of student involvement in their governance as measure of disciplinary management strategy in secondary schools

ii) To establish whether significant differences exist between students' levels of involvement in decision making and incidences of indiscipline in secondary schools

\section{Research methodology}

The study used Descriptive survey design which determines the consequences that arise as a result of influence of principals' involvement of students in decision making and discipline of students in secondary schools in Machakos County Kenya. Orodho (2005) and Kasomo (2006) concur that a target population consists of all the items or people under consideration in any field of inquiry about which the researcher wants to determine some characteristics. At the time of the study, the County had 356 schools translating to 356 principals of public and private schools and 4602 student leaders.

\section{Sample size and sampling procedures}

A sample is a subset of a particular population that represents the whole. Where the population is heterogeneous, a big sample as possible should be taken (Kothari, 2004).There were 356 principals in Machakos County and for a descriptive research, 30 per cent was considered as an effective representation (Mugenda \& Mugenda, 2003), which translated to 118 principals and 13 student leaders from each school. Stratified sampling was applied to capture different subgroups. The sample size was increased to ascertain appropriate representation and avoid sampling error. Stratified sampling was used to present schools by categories, National schools, extracounty schools, county and by type, boys schools, girls boarding, mixed day and boarding and day schools. After stratification, simple random sampling was used to obtain 30 per cent from each type, translating to 118 school principals and 1534 student leaders, a position supported by Kasomo (2006). 


\section{Data collection techniques}

Questionnaires were used for the collection of data from principals and student leaders. Self-developed questionnaires for principals and student leaders were used instruments. Mugenda and Mugenda (2003), affirm that questionnaires offer a considerable advantage in administration and enable the researcher to collect relatively wide range of information in a short period. They also enhance generation of more standardized data. The researcher used focused group discussions for students to gain more insight on the involvement of students in decision making. The instruments were validated by use of expert judgment and their reliability enhanced through test re-test. The reliability of the principals' instrument was 0.73 whereas that of the students' questionnaire was 0.81, implying that the instruments were reliable.

\section{Data analysis techniques}

To establish the focus of mentoring among secondary students, frequencies and percentages were used to present a summary of the matters that were addressed in student mentorship programmes as a form of discipline management mitigation. To determine the whether significant differences existed between the independent and dependent variable, Analysis of Variance was used to test the means at confidence level of $95 \%$.

\section{Instrument return rate}

From a total of 118 questionnaires administered to secondary school principals, 101 were returned translating to a return rate of 85.6 per cent, while all the 108 questionnaires administered to teachers were returned and usable. Out of the 1534 questionnaires administered to students, 1433 of them were returned $(93.4 \%)$.

\section{Results and Discussion}

The first research objective sought to establish the levels of student involvement in their governance as a disciplinary management strategy in secondary schools. The findings indicated high levels of student involvement in in decision making on coordination of class activities $(\mathrm{M}=3.513$, SD. 1.2859), involvement in decision making on students' academics $(\mathrm{M}=3.371$, SD. 1.2558). The findings mirror conventional thinking in secondary schools where students are involved on their management as well as ensuring order and discipline in classes. Similarly, students were equally involved in decision making on games $(\mathrm{M}=3.143)$ as well as decision making on other students' welfare $(M=3.143)$. 
Students were also involved in decision making in other activities but to a less degree. Such involvement was in areas such as making duty rosta, society and clubs, games and sports, coordination of school activities, entertainment schedules, and making decisions on membership of clubs. However, students are not involved in areas such as purchase of school bus, infrastructure development, menu and determining prep hours. Koli (2005) avers that involvement in decision making makes individuals more satisfied with the decisions they have made and lend support to the same.

Qualitative data from interviews from teachers indicated that although many principals wanted to give an impression of compliance with participatory management practices, in essence the involvement was more of a public relations exercise, tokenism because students are kept at bay. This may explain the reason for rampant strikes in the county. The position is supported by Tikoko and Kiprop (2011) who noted that some principals engage in mind games and are not very keen to genuinely involve students in actual governance concerns. The students are only involved in the light concerns but menu which is the cause of many riots is kept off, infrastructure and purchase of school bus. The study established that non-involvement of students in the type and size of buses to purchase, menu, increase in levies, school fees tended to trigger unrest. The study established that the 53 per cent non-involvement in menu decision making can be one of major catalysts to strikes in the county. Similarly, drastic menu changes to the worse without adequate consultations. Such a high percentage of not consulting and the many strikes in the county about the same points to insensitivity on part of the principals that students expressed the desire that the principals whose schools go on strike on the same should be surcharged. Griffins (1994) supported the need for involvement of students who noted that schools that involve students in management have relatively smooth administration.

The involvement of students in class activities is prudent since students spend more time in class than elsewhere. Non-involvement of students in decisions that affect them could make them flout school rules, regulations and general policies. This is supported by Njogu (2003) who observes that student in American high schools are involved in their leadership with a view to nurturing adherence to social order, authority and being responsible. Student leaders feel alienated when they are kept away from decision-making on games, student welfare and academics (Rogers, 2001). Involvement in games makes students relax and so failure to involve them is a recipe for confrontation. Some sporting events are unique like rugby where its ban in a school brought a strike (Sheldon \& Epstein, 2002).

The second research objective sought to determine whether significant differences existed between students' involvement in decision making and incidences of indiscipline. The $\mathrm{F}$ Values indicated 5.43 for 
arson, 3.28 for student bullying, 2.52 for drug and substance abuse and 1.33 for property destruction. This implies that

Table 3: ANOVA on students' involvement in decision making and incidences of indiscipline

\begin{tabular}{llllll|} 
& Sum of Squares & Df & Mean Square & F & Sig. \\
\hline Cases of arson & 1.042 & 4 & .260 & 5.43 & .001 \\
Students bullying & .679 & 4 & .170 & 3.28 & .014 \\
Property destruction & .298 & 4 & .075 & 1.33 & .261 \\
Drug and substance abuse & .538 & 4 & .134 & 2.52 & .046 \\
\cline { 2 - 6 }
\end{tabular}

Table 3 shows that the mean differences between cases of arson, students' bullying and drug and substance abuse were statistically significant; implying that students' involvement in decision making reduces such incidences. However the results also show that the mean difference for property destruction was not statistically significant. This indicates that the mean difference was by pure coincidence and there student's involvement in decision making does not affect property destruction. The principals do not involve students in the main decision making process. They only involve them in simple tasks like making school rules, duty rota, games and sports, clubs and societies and class activities. In many occasions, the issues that students are involved are not contentious and at no time are they cause of strikes and demonstrations in the schools in the county. The study establishes that students are not involved in deciding on school menu which the study establishes is one of the central causes of student unrests. They are not involved in the purchase of the school bus, infrastructure developments which are budgetary considerations and bring tension in the school. The continued occurrence of strikes and discipline cases in schools is because principals do not want to cede ground and allow participatory management practices.

\section{Conclusion}

This study concluded that there was a discrepancy between students' preferred areas of involvement in decision making and what they were actually involved in. whereas principals and teachers wanted to engage in tokenism approach in involving students in governance, students preferred a more radical approach that had enhanced levels of accountability. Involvement could lead to enhanced ownership of the decision making process and adherence to the decision outcome.

Student involvement in decision making enhances discipline in schools with social adjustment, practical competence, self-confidence, selfesteem and sense of been humane. More efforts need to be made to ensure 
that most the administrative decisions are collectively made to enhance discipline in the schools.

\section{Recommendations}

i) The concept of involvement in decision making has made its mark in schools and so the Ministry of Education needs to provide guidelines for of student involvement in governance so that involvement in decision making does not breed anarchy. In addition, involvement in decision making should be anchored on the maturity levels of the learners and not entirely borrowed from the western world without supportive implementation structures

ii) Students need to have regular feedback on different forms of expenditure with a view to removing suspicion that fees increment is done as an avenue of parent exploitation

iii) A policy that any new acquisition and infrastructure development to be fully discussed and agreed on especially new buses for schools for acceptance and aesthetic values.

iv) The Ministry of Education should engage their County agencies more in quality assurance. The focus of quality assurance should not be limited to academic assessments but overall school effectiveness part of which should focus on compliance with participatory governance not only of students but other stakeholders as well

\section{Refferences:}

1. Adesoji, A. O. \& Adetero, J. A. (2015). The effectiveness of student involvement in decision-making and university leadership: A comparative analysis of 12 universities in South-west Nigeria, Journal of Student Affairs in Africa | Volume 3(1) 2015, 65-81, accessed on $14^{\text {th }}$ August, 2017.

2. Barasa, J. (2007). Educational Organisation and management. Nairobi: Jomo Kenyatta Foundation.

3. Chapman, J.D. (2003). School based decision making and management: Implication for school personnel. London: The Palmer Press.

4. Griffin, G. (1996). An Examination of factors contributing to exemplary academic performance in urban public secondary schools in mid-west district. Unpublished doctoral dissertation, Michigan: Western Michigan University.

5. Daft, R.L. \& Marcic, D. (2006). Understanding management. $5^{\text {th }}$ Edition. USA: Thomson South - Western.

6. Grookyalya, N. (2009). A study of social origins and discipline in Makerere College School. Unpublished dissertation, Makerere 
University, Kampala, Uganda.

7. Gumisiriza, M. (1998). The effort of politicisation on discipline in secondary schools in Uganda 1980-1990. Kampala: Makerere University.

8. Hanson, E.M. (1991). Educational Administration and Organisational Behaviour._Boston: Allyn and Bacon.

9. Kabaka, J. N (2005). Influence of head teachers administrative tasks on student discipline in secondary schools. Unpublished M. Ed project, University of Nairobi.

10. Kasomo, D.(2006). Research methods in humanities and education. Eldoret: Zapf chancery.

11. Kato, H. (2007). The impact of the provision of school facilities on students discipline in secondary school in Wakiso district. Published dissertation Makerer University. Kampala, Uganda.

12. Kenya Institute of Education (2008). Secondary school curriculum: Life skills syllabus. Nairobi: Kenya Institute of Education.

13. Kigotho, W. (2009). School strikes: Art of blaming victims. Teacher's Image, 16, 10_11.

14. Kibet, M. J.,Kindiki, J. N., \& Sang', J. K. Principal Leadership and Its Impact on Students Discipline in Kenya Secondary Schools. A Case Study of Koibatek District. Inkanyiso: The Journal of Humanities and Social Sciences, 2012 ISSN 2077 - 2815.

15. Kimotho, N. W. (2012) Influence in student councils' involvement in decision making on discipline in public primary teachers' training colleges in Eastern and Central regions in Kenya, University of Nairobi: Unpublished Research Project

16. Kiprop, C., \& Tikoko, J. (2011). The nature of Student Participation in Decision Making in Secondary Schools: International Journal of Humanities and Social Science, Vol. 2.N.2.

17. Kothari, C.R (2004). Research methodology methods and techniques $2^{\text {nd }}$ edition. New Delhi: New Age International publishers.

18. Muchelle, T.P (1996). Attitudes of secondary school head teachers towards the involvement of students in school administration in Vihiga district, Kenya. M.Ed thesis, University of Nairobi.

19. Mugenda, O.M. \& Mugenda, A.C. (2003)._Research methods quantitative and qualitative approaches. Nairobi: ACTS press.

20. Muli, M. W. (2007). The role of prefects in the governance of Public Secondary Schools in Machakos Central Division, Kenya, Unpublished Master of Education Thesis, Kenyatta University.

21. Mulwa, J. K. (2011). Effects of Principals' use of Alternative Disciplinary Methods on students' discipline in Public secondary schools in Kitui County, Unpublished PhD Thesis, University of 
Nairobi

22. Musyoka, P.D. (2011) Effects of secondary schools prefects' involvement in management of students discipline in Kitui central District, Kenya, Unpublished M.Ed Research project, University of Nairobi.

23. Mutiso, J. (2013). Influence of integrating Prefect council in School Management on Discipline in Public Secondary Schools. Unpublished Master of Education project, University of Nairobi.

24. Mwangi, K. W. (2013) Institutional factors influencing students' involvement in Governance in Public secondary Schools in Kigumo District. Unpublished Master of Education project in Corporate Governance, University of Nairobi.

25. Ndiku, J. N., Simiyu, M.A. \& Achoka, S.K.J (2009). Improving decision-making in Schools through teacher participation- Academic journals. Review Vol. 4(8). Masinde Muliro University of Science and Technology. Educational Research. Retrieved January 24, 2011 from http://www.academicjournals.org.err.

26. Njogu, K. (2004). Potential Leadership Training Grounds: Special Report Student Leadership. East African Standard $2^{\text {nd }}$ September 2004.

27. Okumbe, J. A. (1998). Educational management: Theory and practice. Nairobi: Nairobi University press.

28. Olembo, J.O. (1992). Management in Education. Nairobi: Educational Research and Publications (ERAP).

29. Olengarum, F. (2013). The impact of Students' council the Management of discipline in Public Secondary Schools in Baringo Central Sub County, Unpublished Master of Education Thesis, Kenyatta University.

30. Ombongi, F. M. (2012) Influence of Prefects'Administrative Role on Students' Discipline in Public Secondary Schools in Musaba South District, Kenya. Unpublished Master of Education project, University of Nairobi.

31. Pugh, G. (1989). Parents and professionals in pre-school service: is partnership possible? In S. Woldendate (ed) (2009) parental involvement: development networks between schools, home and community: London: Cassel.

32. Republic of Kenya (2001). Report of the task force on student discipline and unrest in Secondary schools (Wangai Report). Nairobi: Jomo Kenyatta Foundation.

33. Reynolds, D. (Ed) (1989). Effective Schools and pupils behaviour. In N. Jones (Ed) (2001). Management and pupil behaviour. London: The palmer press. 
34. Rogers,B.(2001). Behaviour management. London: Chapman.

35. Seldon, S. B. \& Epstein, J. L. (2000). Improving student behaviour and school discipline with family and community involvement. Education and urban society 35, 4-26.

36. Wambua, P. M. (2017). Influence of principals' participatory management practices on student discipline in secondary schools in Machakos County, Kenya, unpublished $\mathrm{PhD}$ thesis, University of Nairobi. 